\title{
Medium pH between 5.5 and 7.5 has Minimal Effects on Tissue Culture of Apple
}

\author{
Xiaoxin Shi and Lili Yang \\ College of Horticulture, Agricultural University of Hebei, Baoding, Hebei \\ 071001, China
}

\section{Guijun Yan}

School of Plant Biology, Faculty of Science and The UWA Institute of Agriculture, The University of Western Australia, Perth 6009, Australia

\section{Guoqiang Du ${ }^{1}$ \\ College of Horticulture, Agricultural University of Hebei, Baoding, Hebei 071001, China}

Additional index words. Malus domestica, tissue culture, $\mathrm{pH}$ value, ion content change, proliferation and rooting, adventitious bud regeneration from leaves

\begin{abstract}
Medium pH is generally adjusted to 5.8 to 6.0 for plant tissue culture. Our research indicated that $\mathrm{pH}$ generally falls between 5.5 and 7.5 in an ordinarily made medium which can be directly used for apple tissue culture without adjusting $\mathrm{pH}$. Repeated adjustment of $\mathrm{pH}$ by adding $\mathrm{NaOH}$ and $\mathrm{HCl}$ leads to the increase in $\mathrm{Na}^{+}$and $\mathrm{Cl}^{-}$concentration and decrease in $\mathrm{Mg}^{2+}$ and $\mathrm{Ca}^{2+}$ concentration in the medium due to precipitation. To determine the pros, cons, and necessity of $\mathrm{pH}$ levels while making medium in plant tissue culture, subculture proliferation, adventitious root induction, and organ regeneration, the apple cultivars Fuji, Golden Delicious, Jonagold, and Gala were used and hardness of the medium and the ion content of $\mathrm{Na}^{+}, \mathrm{Cl}^{-}, \mathrm{Mg}^{2+}$, and $\mathrm{Ca}^{2+}$ in the medium under different $\mathrm{pH}$ were measured. In the lower $\mathrm{pH}$ range of 5.0-5.5, plantlets could be subcultured and grew normally; however, the medium did not solidify or solidified poorly resulting in problems associated with handling. No significant difference was found among the treatments when $\mathrm{pH}$ ranged 6.0-8.0 in terms of proliferation, adventitious root induction, and adventitious bud regeneration from leaves, except a slight decrease in shoot number proliferation in 'Jonagold' and in adventitious bud regeneration from leaves in 'Fuji' and 'Golden Delicious' at $\mathrm{pH}$ above 7.5. The hardness of the medium increased with the increased $\mathrm{pH}$. The superfluous $\mathrm{Cl}^{-}$and $\mathrm{Na}^{+}$generated during the process of overadjusting $\mathrm{pH}$ to $7.0 \mathrm{by}$ adding $\mathrm{NaOH}$ and then readjusting to 6.0 by adding $\mathrm{HCl}$ significantly affected the proliferation, rooting, and organ regeneration of apple plantlets. A relative broad range of medium pH (5.5-7.5) is suitable for apple tissue culture. We suggest that it is not necessary to always adjust medium $\mathrm{pH}$ to 5.8-6.0 in apple tissue culture; especially the repeated adjustment should be avoided.
\end{abstract}

Plant tissue culture technique has been improved remarkably in the last few decades. The technique is widely used in plant propagation (Pattnaik and Chand, 1997), virus elimination (Ramírez-Malagón et al., 2006; Subba Reddy and Sreenivasulu, 2011), genetic transformation (Falco et al., 2000; Taskin et al., 2003; Xue et al., 1999), germplasm preservation (Forsline et al., 1998; Gagliardi et al., 2002; Orlikowska, 1992; Reed et al., 1998; Zacchini and Agazio, 2004), and secondary metabolite production (Bourgaud et al., 2001; Cheng et al., 2008). The most commonly used culture medium is the Murashige and

Received for publication 6 Oct. 2016. Accepted for publication 22 Dec. 2016.

This work was supported by Nature Science Foundation of Hebei, China (C2012204091, C2014204115) and Hebei Province Hundred Talents Program, China.

${ }^{1}$ Corresponding author. E-mail: gdu@hebau.edu.cn.
Skoog (MS) medium (Murashige and Skoog, 1962) or the variant of it. The $\mathrm{pH}$ of the medium is generally suggested as 5.5-6.0 and not much research on it has been reported (Beyl, 2011).

Generally, the medium is adjusted to a certain $\mathrm{pH}$ depending on the plant species used and the purpose. For example, tetraploid black locust showed the highest proliferation rate at $\mathrm{pH}$ 5.6-6.0, whereas the Erqiao black locust preferred $\mathrm{pH} 6.4$ (Huang and Liu, 2003). Growth and nutrient uptake of teak (Tectona grandis) seedlings in vitro was optimum on a medium at $\mathrm{pH}$ of 6.0 (Hong and Yin, 2010; Zhou et al., 2009). The $\mathrm{pH}$ of the medium is also responsible for the occurrence of vitrification (a phenomenon of plantlets appearing turgid, glaucous, and watery), which has been shown on Prunus salicina within pH 5.4 to 5.8 (Ding et al., 2008). In the case of apple, the medium $\mathrm{pH}$ regulated root formation of the microcuttings of the cultivars Gala and Triple Red Delicious by affecting indole-3-butyric acid (IBA) uptake (Harbage and Stimart, 1996; Harbage et al., 1998), and for cultivar Jork $\mathrm{s}_{9}$, better rooting occurred at pH 5.3 (Klerk et al., 2008).

However, not all plant species are that sensitive to $\mathrm{pH}$ variation of the medium within a certain range. For instance, the proliferation and growth of Oncidium plantlets did not show significant difference with variable $\mathrm{pH}$ from 5.2 to 6.5 (Cui et al., 2004). Likewise, plantlets of Plantago almogravensis and Plantago algarbiensis performed equally with variation of medium $\mathrm{pH}$ from 4.50 to 5.75 (Martins et al., 2011). Although optimal medium $\mathrm{pH}$ varied from plant species to species, in most cases, it is adjusted to the range of 5.0-6.0 (Li, 2002).

Adjusting medium $\mathrm{pH}$ is normally done by adding diluted $\mathrm{HCl}$ or $\mathrm{NaOH}$ solution. In many cases, repeated adjustment by adding $\mathrm{HCl}$ and $\mathrm{NaOH}$ in turn is needed to get an exact $\mathrm{pH}$ value. It is quite understandable that adding these chemicals changes the ion concentration which might have adverse effects on plant growth. The objectives for this study were 1) to analyze the changes of the ion concentration in medium after adjustment of $\mathrm{pH}$, 2) to assess the effect of medium $\mathrm{pH}$ range on apple subculture proliferation, rooting, and adventitious bud regeneration from leaves, and 3 ) to determine the necessity of $\mathrm{pH}$ adjustment while preparing medium for apple tissue culture.

\section{Materials and Methods}

Plant materials. The plantlets of Malus domestica 'Fuji', 'Golden Delicious', 'Jonagold', and 'Gala', and one apple rootstock $\mathrm{M}_{26}$ were studied. These were subcultured in vitro for years using the MS medium containing benzyladenine (BA) $1.0 \mathrm{mg} \cdot \mathrm{L}^{-1}$, naphthaleneacetic acid (NAA) $0.05 \mathrm{mg} \cdot \mathrm{L}^{-1}$, sucrose $35.0 \mathrm{~g} \cdot \mathrm{L}^{-1}$, and agar (from Haiyan Agar Limited, Qingdao, China) $6.0 \mathrm{~g} \cdot \mathrm{L}^{-1}$, in a culture room under the condition of $2000 \mathrm{~lx}$ light intensity with 14-h-photoperiod at $25 \pm 3{ }^{\circ} \mathrm{C}$. The medium $\mathrm{pH}$ was adjusted to $5.8-6.0$ before autoclaving at $121^{\circ} \mathrm{C}$ for $20 \mathrm{~min}$.

Analysis of ion content in different $p H$ medium after adjustment. The MS medium containing BA $1.0 \mathrm{mg} \cdot \mathrm{L}^{-1}$, NAA $0.05 \mathrm{mg} \cdot \mathrm{L}^{-1}$, and sucrose $35.0 \mathrm{~g} \cdot \mathrm{L}^{-1}$ was prepared and divided into four subsets. The $\mathrm{pH}$ of two of them were adjusted to 6.0 and 7.0 by adding $1 \mathrm{~mol} \cdot \mathrm{L}^{-1} \mathrm{NaOH}$ and/or $1 \mathrm{~mol} \cdot \mathrm{L}^{-1} \mathrm{HCl}$ depending on the initial medium $\mathrm{pH}$. The third one was adjusted to 7.0 first, and then readjusted to 6.0 , resulting in three treatments, and the fourth one was taken as control without adjusting $\mathrm{pH}$. The medium $\mathrm{pH}$ was measured using a pH meter (Sartorius PB-10; Germany). The amount of $1 \mathrm{~mol} \cdot \mathrm{L}^{-1} \mathrm{NaOH}$ or $1 \mathrm{~mol} \cdot \mathrm{L}^{-1}$ $\mathrm{HCl}$ added was recorded. Volumetric differences among treatments were equalized by deionized and distilled water. The medium was autoclaved at $121^{\circ} \mathrm{C}$ for $20 \mathrm{~min}$ before use.

The content of $\mathrm{Na}^{+}, \mathrm{Mg}^{2+}$, and $\mathrm{Ca}^{2+}$ ions in the medium was determined by using inductively coupled plasma atomic emission spectrometry (VISTA-MPX, Varian Inc., CA), and 
that of $\mathrm{Cl}^{-}$ion was determined by using ion chromatography (Metrohm 882 Compact IC plus, Herisau, Switzerland).

Effect of medium $\mathrm{pH}$ on proliferation of apple plantlets in vitro. Subculture medium, basic MS containing BA $1.0 \mathrm{mg} \cdot \mathrm{L}^{-1}$, NAA $0.05 \mathrm{mg} \cdot \mathrm{L}^{-1}$, sucrose $35.0 \mathrm{~g} \cdot \mathrm{L}^{-1}$, and agar 6.0 g. $\mathrm{L}^{-1}$ was prepared. Six different media with $\mathrm{pH}$ adjusted to 5.5, 6.0, 6.5, 7.0, and 7.5, and an adjusted 7.0 medium readjusted to 6.0 were used. The subcultured apple plantlets with similar growth status were subcultured onto the medium. Each treatment consisted of 54 plantlets equally distributed in nine $100-\mathrm{mL}$ conical flasks. The number of total new shoots and the effective new shoots that were longer than $1.5 \mathrm{~cm}$ (able to be used for rooting) were recorded at $35 \mathrm{~d}$ after subculture.

Effect of medium $\mathrm{pH}$ on adventitious root induction. New shoots longer than $1.5 \mathrm{~cm}$ were inoculated onto the rooting medium containing $1 / 2$-strength $\mathrm{MS}$, indoleacetic acid 1.0 $\mathrm{mg} \cdot \mathrm{L}^{-1}$, IBA $0.4 \mathrm{mg} \cdot \mathrm{L}^{-1}$, sucrose $25.0 \mathrm{~g} \cdot \mathrm{L}^{-1}$, and agar $6.0 \mathrm{~g} \cdot \mathrm{L}^{-1}$. The $\mathrm{pH}$ of the medium was adjusted as of the subculture experiment. Nine shoots were inoculated in each conical flask. The materials were cultured in a cabinet with a 14-h-photoperiod at $25 \pm 3{ }^{\circ} \mathrm{C}$. Rooting rate, number of roots per plant, and length of roots were recorded $35 \mathrm{~d}$ after inoculation. Rooting rate was calculated as the percentage of the shoots that produced roots.

Effect of medium $\mathrm{pH}$ on adventitious bud induction from leaves in vitro. The top second to fourth leaves (expanding or fully expanded) were collected from the plantlets that subcultured for about $30 \mathrm{~d}$. Each leaf was crosscut twice without breaking and inoculated on the MS medium containing BA $1.0 \mathrm{mg} \cdot \mathrm{L}^{-1}$, thidiazuron $0.5 \mathrm{mg} \cdot \mathrm{L}^{-1}$, NAA $\mathrm{mg} \cdot \mathrm{L}^{-1}$, sucrose $30.0 \mathrm{~g} \cdot \mathrm{L}^{-1}$, and agar $6.0 \mathrm{~g} \cdot \mathrm{L}^{-1}$ with the $\mathrm{pH}$ adjustment as of the above sections. Eight leaves were inoculated in each conical flask. The materials were dark-cultured for $20 \mathrm{~d}$ before light culture with a 16-h-photoperiod at $25 \pm 3{ }^{\circ} \mathrm{C}$. Adventitious bud regeneration rate and number of adventitious buds per leaf were evaluated $30 \mathrm{~d}$ after light culture.

Data and statistical analysis. This research was repeated in years 2009, 2011, and 2012. The result of different years showed very reproducible data. Thus, the data from the year 2012 have been analyzed and interpreted to prepare this manuscript. The experimental design used in this research was completely randomized with three replications. Data were analyzed using analysis of variance of Data Processing System $\left(\right.$ DPS $\left.^{\circledR}\right)$ software (Tang and Feng, 2007; Tang and Zhang, 2013). The percentage data were converted to a decimal value and transformed as the inverse sine of the square root to normalize the data. Treatment differences were tested at the level of $\alpha=0.05$ using Least Significant Ranges means.

\section{Results}

Analysis of ion content in different $p H$ medium. The initial $\mathrm{pH}$ of the MS medium prepared in this experiment was read as 5.1.
Since the initial $\mathrm{pH}$ value was lower than expected, $\mathrm{NaOH}$ was added to the medium to increase the $\mathrm{pH}$ value. As expected, the content of $\mathrm{Na}^{+}$ion was increased due to the addition of $\mathrm{NaOH}$ (Table 1). Likewise, the addition of $\mathrm{HCl}$ to readjust the $\mathrm{pH}$ resulted in the increase of $\mathrm{Cl}^{-}$ion content. However, the content of $\mathrm{Ca}^{2+}$ ion in the solution decreased significantly with the addition of $\mathrm{NaOH}$. The content of $\mathrm{Mg}^{2+}$ ion also changed slightly during this process (Table 1).

Precipitation had been observed as of adding $\mathrm{NaOH}$ while adjusting the medium $\mathrm{pH}$, which is hardly noticed when agar is added during the conventional process of medium preparation. To determine what caused this precipitation, the salts involved in the MS medium formula were used individually in making solution in the same concentration as in the MS medium. Adding $\mathrm{NaOH}$ resulted in precipitation in the solutions made from $\mathrm{CaCl}_{2} \cdot 2 \mathrm{H}_{2} \mathrm{O}$ and $\mathrm{MgSO}_{4} \cdot 7 \mathrm{H}_{2} \mathrm{O}$, which confirmed the above chemical analysis results.

Effect of $\mathrm{pH}$ on hardness of the medium. The medium solidity is dependent on $\mathrm{pH}$ value. When the $\mathrm{pH}$ value was 5.0 , it hardly became solid and the plantlets had to be grown in this medium using sponge as an extra supporting material. Although the plantlets grew normally, this medium did not appear convenient due to the difficulty in handling. It was observed that the medium started to solidify when its $\mathrm{pH}$ reached 5.5, although it was soft and could crack while the conical flask was tilted. The medium solidity was optimal when $\mathrm{pH}$ value ranged from 6.0 to 6.5 . It was noted that when the $\mathrm{pH}$ was adjusted up to 7.0 or higher, the medium became too hard for the tender plantlets to be inoculated which probably affected the nutrition uptake as evidenced by the yellowish leaves. This hard medium also showed a tendency of cracking itself.

Effect of medium $\mathrm{pH}$ on proliferation of subculture. The proliferation efficiency of subculture in four apple varieties and $\mathrm{M}_{26}$ was unaffected by the medium $\mathrm{pH}$ within the range from 5.5 to 7.5 . The number of shoots and the number of effective shoots were not influenced by the tested $\mathrm{pH}$, except for 'Fuji' apple at pH 7.5 (Table 2). It appeared that the apple plantlets were compatible with a wide $\mathrm{pH}$ range of medium during the subculture stage. On the other hand, the readjustment of $\mathrm{pH}$ from 7.0 back to 6.0 significantly lowered the number of shoots and the number of effective shoots in 'Fuji' and 'Jonagold' apple. The readjustment by adding $\mathrm{HCl}$ resulted in the increase of $\mathrm{Cl}^{-}$ion (Table 1). Even though the medium $\mathrm{pH}$ was relatively optimal, the side effect of the ion concentration was prominent.

Effect of medium $\mathrm{pH}$ on adventitious root induction. Root induction was not significantly influenced by medium $\mathrm{pH}$, except for 'Fuji' apple at $\mathrm{pH}$ 7.5, which had significant low rooting (Table 3 ). In the case where $\mathrm{pH}$ was readjusted, lower rooting percentage and number of roots have been recorded in all varieties and $\mathrm{M}_{26}$, although root length was not significantly affected.

Effect of medium $\mathrm{pH}$ on adventitious bud regeneration from leaves. The leaves cut from subcultured plantlets of 'Fuji', 'Golden Delicious', 'Jonagold', 'Gala', and $\mathrm{M}_{26}$ were inoculated onto the medium with different $\mathrm{pH}$ to induce the adventitious buds. The data showed that the adventitious bud regeneration rate and number of buds regenerated per leaf (Table 4) are not significantly influenced by the medium $\mathrm{pH}$. However, the medium of which $\mathrm{pH}$ had been readjusted showed significantly decreased adventitious bud regeneration of 'Fuji', 'Jonagold', and $\mathrm{M}_{26}$, but those of 'Golden Delicious' and 'Gala' were not significantly affected by the readjustment.

\section{Discussion}

Apple is an important fruit species worldwide which can be readily propagated by tissue culture. It has been documented in different plant species that the medium $\mathrm{pH}$ is an important factor for the growth and development of plantlets in vitro. Repeated use of $\mathrm{NaOH}$ and $\mathrm{HCl}$ to adjust the medium $\mathrm{pH}$ results in imbalanced ion concentration in the medium leading to the problem of nutrient uptake by the young plantlets. Thus, the present study investigated the influence of medium $\mathrm{pH}$ on tissue culture performance of different apple cultivars and the consequence of $\mathrm{pH}$ readjustment on growth of apple plantlets.

Our major conclusions are that $\mathrm{pH}$ falls between 5.5 and 7.5 in an ordinarily made medium which can be directly used for apple tissue culture without adjusting $\mathrm{pH}$. Repeated adjustment of $\mathrm{pH}$ by adding $\mathrm{NaOH}$ and $\mathrm{HCl}$ leads to the increase in $\mathrm{Na}^{+}$and $\mathrm{Cl}^{-}$concentration and decrease in $\mathrm{Mg}^{2+}$ and $\mathrm{Ca}^{2+}$ availability in the medium due to precipitation. In the lower $\mathrm{pH}$ range of 5.0-5.5, plantlets could be subcultured and grew normally; however, the medium did not solidify or solidified poorly resulting in problems associated with handling. No significant difference was found among the treatments when $\mathrm{pH}$ ranged from 6.0 to 8.0 in terms of proliferation, adventitious root induction, and adventitious bud regeneration from leaves, except a slight decrease in shoot number proliferation in 'Jonagold' and in adventitious bud regeneration from leaves

Table 1. Effect of $\mathrm{pH}$ adjustment on ion concentration in medium solution.

\begin{tabular}{lcccc}
\hline Medium $\mathrm{pH}$ & $\mathrm{Na}^{+}\left(\mathrm{mg} \cdot \mathrm{L}^{-1}\right)$ & $\mathrm{Cl}^{-}\left(\mathrm{mg} \cdot \mathrm{L}^{-1}\right)$ & $\mathrm{Ca}^{2+}\left(\mathrm{mg} \cdot \mathrm{L}^{-1}\right)$ & $\mathrm{Mg}^{2+}\left(\mathrm{mg} \cdot \mathrm{L}^{-1}\right)$ \\
\hline 5.1 (Initial) & $11.6 \mathrm{c}^{\mathrm{z}}$ & $320.0 \mathrm{~b}$ & $188.0 \mathrm{a}$ & $39.4 \mathrm{a}$ \\
Adjusted to 6.0 & $49.4 \mathrm{~b}$ & $323.1 \mathrm{~b}$ & $160.4 \mathrm{~b}$ & $38.5 \mathrm{a}$ \\
Adjusted to 7.0 & $106.0 \mathrm{a}$ & $321.6 \mathrm{~b}$ & $122.0 \mathrm{c}$ & $35.0 \mathrm{~b}$ \\
Adjusted to 7.0, readjusted to 6.0 & $104.8 \mathrm{a}$ & $363.0 \mathrm{a}$ & $117.2 \mathrm{c}$ & $34.2 \mathrm{~b}$ \\
\hline
\end{tabular}

${ }^{\mathrm{z}}$ Different letters following the data within each column represent the significance at the level of $\alpha=0.05$. 
Table 2. Influence of medium $\mathrm{pH}$ on proliferation efficiency of apple cultivars in vitro.

\begin{tabular}{|c|c|c|c|c|c|c|c|c|c|c|}
\hline \multirow[b]{2}{*}{ Medium pH } & \multicolumn{2}{|r|}{ Fuji } & \multicolumn{2}{|c|}{ Golden Delicious } & \multicolumn{2}{|r|}{ Jonagold } & \multicolumn{2}{|r|}{ Gala } & \multicolumn{2}{|r|}{$\mathrm{M}_{26}$} \\
\hline & $\begin{array}{l}\text { No. of } \\
\text { shoots }\end{array}$ & $\begin{array}{c}\text { No. of } \\
\text { effective shoots }\end{array}$ & $\begin{array}{l}\text { No. of } \\
\text { shoots }\end{array}$ & $\begin{array}{c}\text { No. of } \\
\text { effective shoots }\end{array}$ & $\begin{array}{l}\text { No. of } \\
\text { shoots }\end{array}$ & $\begin{array}{c}\text { No. of } \\
\text { effective shoots }\end{array}$ & $\begin{array}{l}\text { No. of } \\
\text { shoots }\end{array}$ & $\begin{array}{c}\text { No. of } \\
\text { effective shoots }\end{array}$ & $\begin{array}{l}\text { No. of } \\
\text { shoots }\end{array}$ & $\begin{array}{c}\text { No. of } \\
\text { effective shoots }\end{array}$ \\
\hline 5.5 & $5.24 \mathrm{a}^{\mathrm{z}}$ & $2.37 \mathrm{a}$ & $6.36 \mathrm{a}$ & $2.69 \mathrm{a}$ & $4.90 \mathrm{a}$ & $3.47 \mathrm{a}$ & $7.54 \mathrm{a}$ & $3.55 \mathrm{a}$ & $7.80 \mathrm{a}$ & $2.60 \mathrm{a}$ \\
\hline 6.0 & $4.73 \mathrm{ab}$ & $2.03 \mathrm{a}$ & $6.55 \mathrm{a}$ & $3.20 \mathrm{a}$ & $4.23 \mathrm{ab}$ & $3.13 \mathrm{ab}$ & $7.16 \mathrm{a}$ & $2.80 \mathrm{a}$ & $9.33 \mathrm{a}$ & $2.73 \mathrm{a}$ \\
\hline 6.5 & $4.60 \mathrm{ab}$ & $2.30 \mathrm{a}$ & $6.87 \mathrm{a}$ & $2.80 \mathrm{a}$ & $4.13 \mathrm{ab}$ & $3.08 \mathrm{ab}$ & $7.08 \mathrm{a}$ & $2.51 \mathrm{a}$ & $7.93 \mathrm{a}$ & $2.97 \mathrm{a}$ \\
\hline 7.0 & $5.10 \mathrm{a}$ & $1.80 \mathrm{ab}$ & $7.08 \mathrm{a}$ & $2.20 \mathrm{a}$ & $3.89 \mathrm{ab}$ & $2.82 \mathrm{ab}$ & $7.72 \mathrm{a}$ & $2.42 \mathrm{a}$ & $8.00 \mathrm{a}$ & $2.55 \mathrm{a}$ \\
\hline 7.5 & $4.42 \mathrm{ab}$ & $1.50 \mathrm{~b}$ & $6.51 \mathrm{a}$ & $2.51 \mathrm{a}$ & $4.28 \mathrm{ab}$ & $3.24 \mathrm{ab}$ & $7.27 \mathrm{a}$ & $2.31 \mathrm{a}$ & $8.25 \mathrm{a}$ & $3.42 \mathrm{a}$ \\
\hline 6.0 (Readjusted) & $3.93 \mathrm{~b}$ & $1.31 \mathrm{~b}$ & $6.82 \mathrm{a}$ & $2.42 \mathrm{a}$ & $3.40 \mathrm{~b}$ & $2.30 \mathrm{~b}$ & $7.03 \mathrm{a}$ & $2.29 \mathrm{a}$ & $8.47 \mathrm{a}$ & $2.64 \mathrm{a}$ \\
\hline
\end{tabular}

${ }^{\mathrm{z}}$ Different letters following the data within each column represent the significance at the level of $\alpha=0.05$.

Table 3. Effect of medium $\mathrm{pH}$ on rooting ability of apple shoots in vitro.

\begin{tabular}{|c|c|c|c|c|c|c|c|c|c|c|c|c|}
\hline \multirow[b]{2}{*}{ Medium pH } & \multicolumn{3}{|c|}{ Fuji } & \multicolumn{3}{|c|}{ Jonagold } & \multicolumn{3}{|c|}{ Gala } & \multicolumn{3}{|c|}{$\mathrm{M}_{26}$} \\
\hline & $\begin{array}{c}\text { Rooting } \\
(\%)\end{array}$ & $\begin{array}{l}\text { No. of } \\
\text { roots } \\
\text { per plant }\end{array}$ & $\begin{array}{c}\text { Root } \\
\text { length }(\mathrm{cm})\end{array}$ & $\begin{array}{l}\text { Rooting } \\
\quad(\%)\end{array}$ & $\begin{array}{c}\text { No. of } \\
\text { roots } \\
\text { per plant }\end{array}$ & $\begin{array}{c}\text { Root } \\
\text { length }(\mathrm{cm})\end{array}$ & $\begin{array}{c}\text { Rooting } \\
(\%)\end{array}$ & $\begin{array}{l}\text { No. of } \\
\text { roots } \\
\text { per plant }\end{array}$ & $\begin{array}{c}\text { Root } \\
\text { length }(\mathrm{cm})\end{array}$ & $\begin{array}{c}\text { Rooting } \\
(\%)\end{array}$ & $\begin{array}{c}\text { No. of } \\
\text { roots } \\
\text { per plant }\end{array}$ & $\begin{array}{c}\text { Root } \\
\text { length }(\mathrm{cm})\end{array}$ \\
\hline 5.5 & $69.56 \mathrm{a}^{\mathrm{z}}$ & $3.69 \mathrm{a}$ & $3.82 \mathrm{a}$ & $98.90 \mathrm{a}$ & $4.63 \mathrm{a}$ & $4.21 \mathrm{a}$ & $100.00 \mathrm{a}$ & $6.63 \mathrm{a}$ & $4.57 \mathrm{a}$ & $100.00 \mathrm{a}$ & $7.54 \mathrm{a}$ & $5.92 \mathrm{a}$ \\
\hline 6.0 & $78.21 \mathrm{a}$ & $3.76 \mathrm{a}$ & $3.25 \mathrm{a}$ & $100.00 \mathrm{a}$ & $4.48 \mathrm{a}$ & $4.05 \mathrm{a}$ & $94.23 \mathrm{a}$ & $6.12 \mathrm{a}$ & $4.26 \mathrm{a}$ & $100.00 \mathrm{a}$ & $7.30 \mathrm{a}$ & $5.00 \mathrm{a}$ \\
\hline 6.5 & $70.23 \mathrm{a}$ & $3.65 \mathrm{a}$ & $2.89 \mathrm{a}$ & $98.02 \mathrm{a}$ & $3.83 \mathrm{a}$ & $4.02 \mathrm{a}$ & $100.00 \mathrm{a}$ & $5.16 \mathrm{a}$ & $4.20 \mathrm{a}$ & $97.63 \mathrm{a}$ & $5.40 \mathrm{a}$ & $4.72 \mathrm{a}$ \\
\hline 7.0 & $73.94 \mathrm{a}$ & $3.09 \mathrm{ab}$ & $3.63 \mathrm{a}$ & $89.56 \mathrm{ab}$ & $4.34 \mathrm{a}$ & $4.72 \mathrm{a}$ & $93.30 \mathrm{a}$ & $5.02 \mathrm{a}$ & $3.28 \mathrm{a}$ & $97.63 \mathrm{a}$ & $5.40 \mathrm{a}$ & $4.26 \mathrm{a}$ \\
\hline 7.5 & $52.31 \mathrm{~b}$ & $2.89 \mathrm{~b}$ & $2.56 \mathrm{a}$ & $88.30 \mathrm{ab}$ & $3.38 \mathrm{a}$ & $4.62 \mathrm{a}$ & $98.30 \mathrm{a}$ & $6.32 \mathrm{a}$ & $4.74 \mathrm{a}$ & $89.56 \mathrm{ab}$ & $6.33 \mathrm{a}$ & $3.97 \mathrm{a}$ \\
\hline 6.0 (Readjusted) & $40.23 \mathrm{~b}$ & $1.83 \mathrm{c}$ & $2.23 \mathrm{a}$ & $66.67 \mathrm{~b}$ & $3.17 \mathrm{a}$ & $3.83 \mathrm{a}$ & $74.26 \mathrm{~b}$ & $5.78 \mathrm{a}$ & $4.79 \mathrm{a}$ & $68.96 \mathrm{~b}$ & $5.00 \mathrm{a}$ & $5.09 \mathrm{a}$ \\
\hline
\end{tabular}

${ }_{\mathrm{z}}$ Different letters following the data within each column represent the significance at the level of $\alpha=0.05$.

Table 4. Effect of medium $\mathrm{pH}$ on adventitious bud regeneration from leaf explants of apple in vitro.

\begin{tabular}{|c|c|c|c|c|c|c|c|c|c|c|}
\hline \multirow[b]{2}{*}{ Medium $\mathrm{pH}$} & \multicolumn{2}{|l|}{ Fuji } & \multicolumn{2}{|c|}{ Golden Delicious } & \multicolumn{2}{|l|}{ Jonagold } & \multicolumn{2}{|l|}{ Gala } & \multicolumn{2}{|l|}{$\mathrm{M}_{26}$} \\
\hline & Regeneration (\%) & $\begin{array}{l}\text { No. of } \\
\text { buds }\end{array}$ & Regeneration (\%) & $\begin{array}{c}\text { No. of } \\
\text { buds }\end{array}$ & Regeneration (\%) & $\begin{array}{l}\text { No. of } \\
\text { buds }\end{array}$ & $\begin{array}{c}\text { Regeneration } \\
(\%)\end{array}$ & $\begin{array}{l}\text { No. of } \\
\text { buds }\end{array}$ & Regeneration (\%) & $\begin{array}{l}\text { No. of } \\
\text { buds }\end{array}$ \\
\hline 5.5 & $46.60 \mathrm{a}^{\mathrm{z}}$ & $2.33 \mathrm{a}$ & $96.91 \mathrm{a}$ & $16.57 \mathrm{a}$ & $100.00 \mathrm{a}$ & $16.72 \mathrm{a}$ & $100.00 \mathrm{a}$ & $35.12 \mathrm{a}$ & $100.00 \mathrm{a}$ & $25.71 \mathrm{a}$ \\
\hline 6.0 & $50.00 \mathrm{a}$ & $2.78 \mathrm{a}$ & $95.34 \mathrm{a}$ & $19.07 \mathrm{a}$ & $97.63 \mathrm{ab}$ & $16.93 \mathrm{a}$ & $99.48 \mathrm{a}$ & $29.07 \mathrm{a}$ & $100.00 \mathrm{a}$ & $21.13 \mathrm{a}$ \\
\hline 6.5 & $39.34 \mathrm{a}$ & $2.25 \mathrm{a}$ & $93.39 \mathrm{a}$ & $17.78 \mathrm{a}$ & $83.05 \mathrm{bc}$ & $16.90 \mathrm{a}$ & $99.51 \mathrm{a}$ & $29.13 \mathrm{a}$ & $98.34 \mathrm{a}$ & $19.03 \mathrm{a}$ \\
\hline 7.0 & $44.35 \mathrm{a}$ & $3.50 \mathrm{a}$ & $89.50 \mathrm{a}$ & $14.81 \mathrm{a}$ & $95.77 \mathrm{abc}$ & $15.33 \mathrm{ab}$ & $98.05 \mathrm{a}$ & $29.63 \mathrm{a}$ & $99.30 \mathrm{a}$ & $21.07 \mathrm{a}$ \\
\hline 7.5 & $41.54 \mathrm{a}$ & $2.33 \mathrm{a}$ & $89.07 \mathrm{a}$ & $16.44 \mathrm{a}$ & $89.23 \mathrm{abc}$ & $15.81 \mathrm{ab}$ & $100.00 \mathrm{a}$ & $24.34 \mathrm{a}$ & $92.11 \mathrm{a}$ & $17.27 \mathrm{ab}$ \\
\hline 6.0 (Readjusted) & $16.06 \mathrm{~b}$ & $0.92 \mathrm{~b}$ & $93.07 \mathrm{a}$ & $18.84 \mathrm{a}$ & $75.05 \mathrm{c}$ & $9.29 \mathrm{~b}$ & $100.00 \mathrm{a}$ & $33.77 \mathrm{a}$ & $74.79 \mathrm{~b}$ & $14.83 \mathrm{~b}$ \\
\hline
\end{tabular}

${ }_{\mathrm{z}}$ Different letters following the data within each column represent the significance at the level of $\alpha=0.05$.

in 'Fuji' and 'Golden Delicious' at $\mathrm{pH}$ above 7.5. The hardness of the medium increased with increased $\mathrm{pH}$. The superfluous $\mathrm{Cl}^{-}$and $\mathrm{Na}^{+}$ generated during the process of overadjusting $\mathrm{pH}$ to 7.0 by adding $\mathrm{NaOH}$ and then readjusting to 6.0 by adding $\mathrm{HCl}$ significantly affected the proliferation, rooting, and organ regeneration of apple plantlets.

In most cases, the medium $\mathrm{pH}$ ranging from 5.8 to 6.0 was considered as optimal for tissue culture. The initial $\mathrm{pH}$ of the medium could be varied depending on the medium components (Bennett et al., 2003; Woodward et al., 2006), the water used (Beyl, 2011), and the ways whether acid or alkaline solution was used for the plant growth regulator to dissolve. In this research, a wider $\mathrm{pH}$ range (5.5 to 7.5) was tested to get a better understanding. In our experiment, the initial medium $\mathrm{pH}$ was 5.1 in the ready-made MS medium. BA was one of the most common plant growth regulators used in plant tissue culture and was dissolved in $1 \mathrm{~mol} \cdot \mathrm{L}^{-1} \mathrm{HCl}$ normally as a stock solution. For MS medium preparation, the $\mathrm{pH}$ could be lowered by adding BA that was prepared by dissolving in $\mathrm{HCl}$, resulting in poor solidity of the medium and more $\mathrm{NaOH}$ was needed for the $\mathrm{pH}$ adjustment. Therefore, $\mathrm{NaOH}$ solution was added to increase the $\mathrm{pH}$ value and the concentration of $1 \mathrm{~mol} \cdot \mathrm{L}^{-1} \mathrm{NaOH}$ is recommended in this process. However, the results of this experiment clearly indicate that adding $\mathrm{NaOH}$ changed the ion concentration of medium solution. And this is particularly true in the case where addition of $\mathrm{NaOH}$ and $\mathrm{HCl}$ was implemented to readjust the medium $\mathrm{pH}$. This ion concentration change showed adverse influence on plant nutrient uptake. Moreover, precipitation was found in the solution during the process of $\mathrm{pH}$ adjustment, and the reaction of $\mathrm{Mg}^{2+}$ and $\mathrm{Ca}^{2+}$ with $\mathrm{OH}^{-}$contributed to this phenomenon, which led to changes in some ion concentrations in the medium. In the real operating process, this phenomenon was hardly noticed due to the presence of agar.

The medium $\mathrm{pH}$ has considerable influence on the physical strength or hardness of the medium which has also been reported in several works on different species. The medium was too soft and had a poor solidity at the $\mathrm{pH}$ lower than 5.5, which posed a handling problem. Thus, it is not recommended to use such a low $\mathrm{pH}$ unless specifically needed for some species. In this work, the plantlets of four apple cultivars and a rootstock $\mathrm{M}_{26}$ showed broad medium $\mathrm{pH}$ adaptability in the aspects of subculture proliferation efficiency, rooting, and adventitious bud regeneration from leaves. But the $\mathrm{pH}$ readjustment resulted in significant limitation in plantlet growth and regeneration, especially in rooting. The changes in some ion concentrations, especially the increase of $\mathrm{Cl}^{-}$ion, could be one of the most important reasons. Thus, the most important conclusion from this research is that for apple tissue culture it is not recommended to adjust medium $\mathrm{pH}$ when it ranges from 5.5 to 7.5. Particularly, the readjustment using $\mathrm{HCl}$ and $\mathrm{NaOH}$ in turn should be avoided as this changes the concentration or availability of some ions.

It was also found that the influence of the $\mathrm{pH}$ adjustment is variable among apple cultivars. 'Gala' appeared as the most sensitive to medium $\mathrm{pH}$, whereas 'Golden Delicious' and $\mathrm{M}_{26}$ showed almost no effect by the medium $\mathrm{pH}$ difference in the culture. 'Fuji' was relatively difficult to root and regenerate, and showed sensitivity to the changes of culture conditions. However, the mechanism of this effect was still unclear. Some scientists have reported that the medium $\mathrm{pH}$ could influence the membrane permeability, the respiratory metabolism, polyamine metabolism, protein synthesis, and the activity of hormones, and indirectly affected the growth and development of the culture materials (Cao and Han, 2003; Ding et al., 2008; Zhang, 2006). Sometimes proliferation or rooting problems were encountered even though the same routine protocol was used. The precipitation and change of ion concentration due to the $\mathrm{pH}$ adjustment reported in this research might provide a solution to these problems. 


\section{Literature Cited}

Bennett, I.J., D.A.J. McDavid, and J.A. McComb. 2003. The influence of ammonium nitrate, $\mathrm{pH}$ and indole butyric acid on root induction and survival in soil of micropropagated Eucalyptus globubus. Biol. Plant. 47:355-360.

Beyl, C. 2011. Getting started with tissue culture: Media preparation, sterile technique, and laboratory equipment, p. 11-26. In: R. Trigiano and D. Gray (eds.). Plant tissue culture, development, and biotechnology. CRC Press, Boca Raton, FL.

Bourgaud, F., A. Gravot, S. Milesi, and E. Gontier. 2001. Production of plant secondary metabolites: A historical perspective. Plant Sci. 161:839-851.

Cao, X.X. and X.Y. Han. 2003. pH value in the culture of the tissue of plants. J. Hangzhou Teachers College (Natural Science Edition) 2:60-63.

Cheng, D.M., G.G. Yousef, M.H. Grace, R.B. Rogers, J. Gorelick-Feldman, I. Raskin, and M.A. Lila. 2008. In vitro production of metabolism-enhancing phytoecdysteroids from Ajuga turkestanica. Plant Cell Tissue Organ Cult. 93:73-83.

Cui, G., Y. Liu, and Y. Gu. 2004. Effects of agar concentration, $\mathrm{pH}$ value and inoculated shoot size on propagation of Oncidium test-tube plantlet. J. Biol. 21:29-31.

Ding, Y., Y. Qiao, Zh. Zhang, Zh. Dong, and Zh. Gao. 2008. Proliferation and rooting from in vitro shoots of Prunus salicina Lindl. 'Xiaohuangli'. Xibei Zhiwu Xuebao 28:969-973.

Falco, M.C., A.T. Neto, and E.C. Ulian. 2000. Transformation and expression of a gene for herbicide resistance in a Brazilian sugarcane. Plant Cell Rpt. 19:1188-1194.

Forsline, P.L., L.E. Towill, J. Waddell, C. Stushnoff, W. Lamboy, and J.R. McFerson. 1998. Recovery and longevity of cryopreserved dormant apple buds. J. Amer. Soc. Hort. Sci. 123:365370.

Gagliardi, R.F., G.P. Pacheco, J.F.M. Valls, and E. Mansur. 2002. Germplasm preservation of wild Arachis species through culture of shoot apices and axillary buds from in vitro plants. Biol. Plant. 45:353-357.
Harbage, F. and P. Stimart. 1996. Effect of $\mathrm{pH}$ and 1H-indole-3-butyric acid (IBA) on rooting of apple microcuttings. J. Amer. Soc. Hort. Sci. 121:1049-1053.

Harbage, F., P. Stimart, and C. Auer. 1998. pH affects $1 \mathrm{H}$-indole-3-butyric acid uptake but not metabolism during the initiation phase of adventitious root induction in apple microcuttings. J. Amer. Soc. Hort. Sci. 123:6-10.

Hong, S. and M. Yin. 2010. The optimization for high-frequency proliferation of adventitious buds of Emmenopterys henryi Oliv. J. Nuclear Agr. Sci. 24:532-536.

Huang, C. and Q. Liu. 2003. The effects of growth regulator, ventilation and $\mathrm{pH}$ value on the in vitro growth of tetraploidy and Erqiao black locust. J. Cent. South Forestry Univ. 23:38-41.

Klerk, J., J. Hanecakova, and J. Jasik. 2008. Effect of medium-pH and MES on adventitious root formation from stem disks of apple. Plant Cell Tissue Organ Cult. 95:285-292.

Li, J. 2002. An introduction to plant tissue culture. 2nd ed. China Agricultural University Press, Beijing, China.

Martins, N., S. Goncalves, T. Palma, and A. Romano. 2011. The influence of low $\mathrm{pH}$ on in vitro growth and biochemical parameters of Plantago almogravensis and P. algarbiensis. Plant Cell Tissue Organ Cult. 107:113-121.

Murashige, T. and F. Skoog. 1962. A revised medium for rapid growth and bio-assays with tobacco tissue cultures. Physiol. Plant 15:473-497.

Orlikowska, T. 1992. Effects of in vitro storage at $4^{\circ} \mathrm{C}$ on survival and proliferation of two apple rootstocks. Plant Cell Tissue Organ Cult. $31: 1-7$.

Pattnaik, S.K. and P.K. Chand. 1997. Rapid clonal propagation of three mulberries, Morus cathayana Hemsl., M. lhou Kois. and M. serrata Roxb., through in vitro culture of apical shoot buds and nodal explants from mature trees. Plant Cell Rpt. 16:503-508.

Ramírez-Malagón, R., L. Pérez-Moreno, A. Borodanenko, G.J. Salinas-González, and N. Ochoa-Alejo. 2006. Differential organ infection studies, potyvirus elimination, and field performance of virus-free garlic plants produced by tissue culture. Plant Cell Tissue Organ Cult. 86:103110.

Reed, B.M., J. Denoma, J. Luo, Y.J. Chang, and L. Towill. 1998. Cryopreservation and long-term storage of pear germplasm. In Vitro Cell. Dev. Biol. Plant 34:256-260.

Subba Reddy, Ch.V. and P. Sreenivasulu. 2011. Generation of sugarcane streak mosaic virusfree sugarcane (Saccharum spp. hybrid) from infected plants by in vitro meristem tip culture. Eur. J. Plant Pathol. 130:597-604.

Tang, Q. and M. Feng. 2007. DPS Data Processing System: Experimental design, statistical analysis, and data mining. Science Press, Beijing, China.

Tang, Q. and C. Zhang. 2013. Data Processing System (DPS) software with experimental design, statistical analysis and data mining developed for use in entomological research. Insect Sci. 20:254-260.

Taskin, K.M., K.A. Turgut, G. Ercan, and R.J. Scott. 2003. Agrobacterium-mediated transformation of Arabis gunnisoniana. Plant Cell Tissue Organ Cult. 72:173-180.

Woodward, J., J. Bennett, and S. Pusswon. 2006. The effect of nitrogen source and concentration, medium $\mathrm{pH}$ and buffering on in vitro shoot growth and rooting in Eucalyptus marginata. Scientia Hort. 110:208-213.

Xue, B., K.S. Ling, C.L. Reid, S. Krastanova, M. Sekiya, E.A. Momol, S. Süle, J. Mozsar, D. Gonsalves, and T.J. Burr. 1999. Transformation of five grape rootstocks with plant virus genes and a virE2 gene from Agrobacterium tumefaciens. In Vitro Cell. Dev. Biol. Plant 35:226-231.

Zacchini, M. and M. Agazio. 2004. Micropropagation of a local olive cultivar for germplasm preservation. Biol. Plant. 48:589-592.

Zhang, Y. 2006. Factors relating to success in plant tissue culture. Northern Hort. 3:132-133.

Zhou, Z., D. Xu, K. Ling, L. Huang, and Zh. Qiu. 2009. Effects of calcium ions and $\mathrm{pH}$ values on the growth and nutrient uptake of teak (Tectona grandis) tube seedlings. J. Cent. South Univ. Forestry Technol 29:1-5. 